\title{
PENERAPAN MODEL ELICITING ACTIVITIES (MEAs) BERBANTUAN MASALAH OPEN ENDEDUNTUK MENINGKATKAN PEMAHAMAN KONSEP MATEMATIKA SISWA
}

\author{
L. G. A. K.Dewi, I. G. N. Y. Hartawan, I. W. P. Astawa \\ Jurusan Matematika, Universitas Pendidikan Ganesha, Singaraja \\ Jurusan Matematika, Universitas Pendidikan Ganesha, Singaraja \\ e-mail:anandakusumadew@gmail.com,hartawan.math@gmail.com, iwp.astawa@yahoo.co.id.
}

\begin{abstract}
Abstrak
Penelitian ini bertujuan untukmendeskripsikan peningkatan pemahaman konsep matematika siswadan mengetahui tanggapan siswa terhadap pembelajaran MEAs berbantuan masalah open ended. Jenis penelitian ini adalah penelitian tindakan kelas yang dilaksanakan dalam tiga siklus. Subjek penelitian ini adalah siswa kelas X IPA 3 SMA Negeri 1 Baturiti sebanyak 34 siswa pada semester ganjil Tahun Ajaran 2018/2019. Data pemahaman konsep matematika siswa diukur menggunakan tes pemahaman konsep berbentuk uraian. Data tanggapan siswa diukur menggunakan angket. Data yang diperoleh dianalisis secara deskriptif. Hasil penelitian menunjukkan bahwa rata-rata nilai pemahaman konsep tiap siklusnya, yaitu 66,$20 ; 69,70 ; 75,20$ dengan ketuntasan belajar siswa mengalami peningkatan tiap siklusnya, yaitu 38,24\%; 52,94\%; 67,65\%. Peningkatan ini tercapai karena adanya pengkolaborasian antara pembelajaran MEAs dengan masalah open ended yang membantu siswa mengembangkan kreatifitas dalam mengekpresikan ide ataupun gagasannya yang akan menjadikan peningkatan pemahamankonsep siswa optimal. Selain itu siswa merepon positif penerapan model eliciting activities (MEAs)berbantuan masalah open ended.
\end{abstract}

Kata-kata Kunci:MEAs,open ended, pemahaman konsep matematika, tanggapan siswa

\begin{abstract}
This study aimed to describe the increase in understanding of students' mathematical concepts and to know student responses through the application of model eliciting activities (MEAs) assisted by open ended problems. This type of research used classroom action research conducted in three cycles. The subjects of this study were 34 students of class X IPA 3 SMA Negeri 1 Baturiti in the odd semester of Academic Year 2018/2019. Data understanding of students' mathematical concepts was measured using concept comprehension tests in the form of descriptions. Student response data was measured using a questionnaire. The data obtained were analyzed descriptively. The results showed that average value of understanding concepts from cycle to cycle in a row, namely $66.2,69.70,75.20$ with an students' mastery learning had increased from cycle to cycle respectively, namely $38.24 \%$, $52.94 \%, 67.65 \%$. This increase was achieved because of the collaboration between MEAs learning with open ended problems that helped students develop their creativity in expressing their ideas ehich would improving students' understanding concepts optimally. In addition, students responded positively to model eliciting activities (MEAs) with the help of open ended problems.
\end{abstract}

Key words: MEAs, open ended, concept understanding, student responses

\section{PENDAHULUAN}

Matematika merupakan ilmu pengetahuan yang penting untuk dikuasai. Matematika terdiri dari konsep-konsep abstrak yang bersifat hierarkis, sehingga pemahaman konsep pada jenjang pendidikan yang lebih rendah merupakan prasyarat bagi pemahaman konsep pada jenjang lebih tinggi. Kurangnya dalam memahami konsep prasyarat menimbulkan bagi siswa dalam mempelajari konsep-konsep selanjutnya yang akan berdampak pada hasil belajar siswa (Diasih, 2014). 
Banyak permasalahan yang menjadi faktor penyebab hasil belajar siswa rendah. Beberapa permasalahan dalam hasil belajar matematika juga dirasakan terjadi di kelas $X$ IPA 3 SMA Negeri 1 Baturiti. Berdasarkan hasil observasi kelas yang dilakukan, ditemukan suatu kondisi bahwa siswa masih mengalami kesulitan dalam menyelesaikan permasalahan matematika yang berbeda dari permasalahan yang diberikan sebelumnya. Hal tersebut menunjukkan bahwa siswa belum memahami konsep dengan baik. Jika konsep dasar yang diterima peserta didik salah, maka sulit untuk memperbaiki kembali terutama jika sudah diterapkan dalam penyelesaian suatu permasalahan, sehingga penting sekali untuk membuat peserta didik memahami konsep dari suatu materi. Konsep-konsep matematika tersusun secara hierarkis, terstruktur, logis, dan sistematis mulai dari konsep yang paling sederhana sampai pada konsep yang paling kompleks. Dalam matematika terdapat topik atau konsep prasyarat sebagai dasar untuk memahami konsep-konsep selanjutnya. Menurut National Council of Teachers of Mathematics (NCTM) (2000), siswa dikatakan memiliki pemahaman konsep matematika jika memenuhi ketiga indikator, yaitu: mampu menyatakan ulang konsep dengan menggunakan kata-kata sendiri (describe concepst in their own words), mengidentifikasi atau memberikan contoh dan bukan contoh dalam konsep (identify or give example and non example of consepts), sertamenggunakan konsep dengan benar di dalam berbagai situasi (use concept correctly in a variety of situations). Karena hal ini, diduga penyebab rendahnya hasil belajar matematika siswa kelas X IPA 3 yaitu pemahaman konsep matematika yang dimiliki siswa masih tergolong rendah.

Pada saat observasi di kelas, juga ditemukan beberapa permasalahan yang diduga sebagai faktor penyebab rendahnya pemahaman konsep matematika siswa kelas X IPA 3 SMA Negeri 1 Baturiti. Adapun permasalah-permasalahan yang ditemukan sebagai berikut.

Pertama, pembelajaran di kelas diawali dengan penyajian konsep yang akan dipelajari secara singkat. Setelah itu, siswa diminta untuk mengerjakan soal latihan yang ada di buku. Pembelajaran hanya difokuskan pada kemampuan siswa dalam menghitung dan mendapatkan jawaban yang benar dari hasil perhitungan yang dilakukan. Siswa pun juga hanya fokus pada penyelesaian soal yang menyebabkan siswa tidak mampu memahami konsep dengan maksimal.

Kedua, siswa kesulitan dalam mengaplikasikan konsep yang dimiliki untuk memecahkan suatu permasalahan, ini terlihat ketika guru memberikan permasalahan siswa terlihat bingung dalam memahami kalimat atau pernyataan pada soal sehingga apa yang diketahui dan apa yang ditanyakan belum bisa artikan dengan benar.

Ketiga, siswa belum mampu mengaitkan pengetahuan yang telah dipelajari sebelumnya dengan pengetahuan baru yang akan siswa pelajari, ini nampak ketika guru memberi materi baru yang ada kaitannya dengan materi sebelumnya siswa terlihat kebingungan dan lupa.

Keempat, siswa belum mampu dalam membuat atau menarik kesimpulan berupa argumen dari siswa itu sendiri dalam memperkuat jawabannya. Keadaan ini mengakibatkan kurangnya pemahaman konsep yang dimiliki siswa, lebih tepatnya pada indikator menyatakan ulang kembali konsep dengan kata-kata sendiri serta menjelaskan contoh dan bukan contoh.

Kelima, guru berupaya untuk melakukan pembelajaran inovatif akan tetapi dalam penerapannya guru masih mendominasi kegiatan pembelajaran. Dilihat dari guru menjelaskan langsung konsep-konsep dan memberikan permasalahan langsung dengan penyelesaiannya, sehingga siswa kurang diberi kesempatan dalam menemukan konsep sendiri, dan mengakibatkan konsep tidak lama diingat dan pembelajaran menjadi kurang bermakna.

Keenam, pembelajaran di kelas kurang memanfaatkan kelompok, sehingga kurang adanya diskusi atau kegiatan tanya jawab antara guru dengan siswa maupun siswa dengan siswa, atau dapat dikatakan kelas pasif.

Sehubungan dengan identifikasi permasalahan di atas, dapat disimpulkan bahwa permasalahan yang terdapat di kelas X IPA 3 SMA Negeri 1 Baturiti adalah rendahnya 
kemampuan pemahaman konsep yang dimiliki siswa dalam kegiatan pembelajaran. Hal ini didukung dari hasil tes awal yang dilakukan untukmengetahui atau mengukur sejauh mana pemahaman konsep siswa, penelitii melakukan tes awal yang terdiri dari dua soal terhadap 34 siswa diperoleh rata-rata nilai siswa pada tes awal adalah 48,9, serta siswa pada kategori tuntas hanya $23,53 \%$. Oleh karena itu, kemampuan pemahaman konsep siswatersebut perlu mendapat perhatian dan jalan keluar yang tepat. Salah satu alternatif untuk meningkatkan kemampuan pemahaman konsep matematika siswa yaitu dengan menerapkan model pembelajaran MEAs.Model eliciting activities(MEAs) merupakan model pembelajaran yang menekankan pada kemampuan menghubungkan ide matematika dengan fenomena atau kejadian nyata (Lesh dan Doer, 2003). Model ini merupakan model pembelajaran yang berupaya membuat siswa dapat secara aktif terlibat dalam proses pembelajaran matematika di kelas, sehingga siswa diberikan kesempatan agar dapat menemukan konsep dan pemahamannya sendiri. MEAs juga didasarkan pada situasi kehidupan nyata siswa, bekerja dalam kelompok kecil sehingga pada pembelajaran di kelas akan terjadinya diskusi dan kegiatan tanya jawab antar siswa maupun siswa ke guru, dan menyusun serta menyajikan sebuah model sebagai proses pemodelan matematika.

Model pembelajaran MEAs terdiri dari tujuh langkah, yaitu: (1) mencermati masalah, (2) memberikan jawaban sementara atas permasalahan, (3) mendiskusikan solusi permasalahan, (4) menyempurnakan solusi permasalahan, (5) membuat penyelesaian matematis untuk menyelesaikan masalah, (6) menguji dan merevisi solusi permasalahan, dan (7) mempresentasikan solusi permasalahan.

Model pembelajaran MEAs diyakini sesuai untuk meningkatkan kemampuan pemahaman konsep matematika siswa dilihat dari hubungan langkah-langkah MEAs dengan indikator pemahaman konsep. Saat mencermati masalah, siswa akanmelihat permasalahan yang diberikan, dalam tahap ini siswa akan mencermati pemilihan metode yang akan digunakan atau tidak. Dengan kata lain, siswa mengidentifikasikan mana yang termasuk contoh dan bukan contoh dalam suatu materi. Pada tahap memberikan jawaban sementara atas permasalahan, siswa dapat menuliskan konsep dengan kata-katanya sendiri. Dalam tahap mendiskusikan solusi permasalahan siswa akan mengaplikasikan konsep yang telah dipelajari terhadap berbagai situasi yang diberikan. Pada tahap membuat penyelesaian sistematis siswa akan menuliskan penyelesaian dengan bahasanya sendiri dan mengaplikasikan konsep tersebut. Pada tahap mempresentasikan solusi, siswa telah mengalami proses ketiga dari indikator pemahaman konsep tersebut. Hal ini didukung dari hasil penelitian Martil (2015) menyatakan bahwa kemampuan pemahaman konsep matematika siswa yang memperoleh pembelajaran dengan model MEAs lebih baik daripada siswa yang memperoleh pembelajaran konvensional.

Selama ini, masalah atau soal yang diberikan oleh guru maupun yang ada pada buku pelajaran matematika cenderung bersifat tertutup. Hal ini menyebabkan siswa hanya terpaku pada cara pengerjaan yang sebelumnya sudah diberikan oleh guru sehingga siswa tidak mampu mengembangkan ide-ide yang dimiliki. Selain itu, siswa juga hanya fokus pada hasil akhir. Hal ini menyebabkan pembelajaran menjadi kurang bermakna dan konsep yang dimiliki oleh siswa hanya bertahan sementara saja. Oleh karena itu, perlu dilakukan suatu usaha agar siswa mampu mengembangkan kemampuan bernalarnya, yaitu dengan diberikannya soal yang bersifat terbuka (open ended).

Masalah open ended dipilih sebagai bantuan untuk mengoptimalkan peningkatan pemahaman konsep matematika dalam penelitian ini karena open ended adalah pembelajaran terbuka yang memberikan kebebasan individu untuk mengembangkan berbagai cara dan strategi pemecahan masalah sesuai dengan kemampuan masing-masing peserta didik (Suherman, 2003). Pembelajaran berbantuan masalahopen ended memberikan ruang yang cukup bagi siswa untuk mengeksplorasi permasalahan sesuai kemampuan, bakat, dan minatnya, sehingga siswa yang memiliki kemampuan yang lebih tinggi dapat berpartisipasi dalam berbagai kegiatan matematika, dan siswa dengan kemampuan lebih rendah masih dapat menikmati kegiatan matematika sesuai dengan kemampuannya.

Jurnal Pendidikan dan Pembelajaran Matematika Indonesia| 135 
MEAs berbantuan masalah open ended memberikan kesempatan bagi siswa untuk analisis dan penalaran dalam pembelajaran sekaligus mengkaitkannya dengan situasi di dunia nyata. Dimana tujuannya untuk memberikan siswa ruang gerak untuk menemukan konsep yang ingin dipelajari melalui proses penemuan dari langkah pembelajaran model eliciting activities dan didukung dengan masalahopen ended yang tercermin dari gaya membelajarkan siswa dengan persoalan yang diberikan diawal diberikan gaya belajar yang soal-soalnya adalah berupa soal-soal open ended. Siswa akan dihadapkan dengan masalah open ended, tujuan utamanya bukan untuk mendapatkan hasil semata tetapi lebih menekankan pada cara bagaimana sampai pada suatu jawaban. Sehingga dengan demikian pembelajaran model eliciting activitiesberbantuan masalahopen ended yang diterapkan dalam pembelajaran akan saling mendukung dalam tujuannya untuk meningkatkan kemampuan pemahaman konsep matematika siswa, hal ini didukung penelitian yang dilakukan oleh Purnamasari (2014) yang menyatakan bahwa penyajian masalah open ended merupakan alternatif yang tepat dalam mengembangkan kemampuan pemahaman konsep matematika dan kemampuan berpikir kreatif.

Berdasarkan paparan tersebut, maka tujuan pada penelitian ini bertujuan untuk mendeskripsikan dan mengetahui peningkatan pemahaman konsep matematika siswa kelas $X$ IPA 3 SMA Negeri 1 Baturiti dapat terjadi dengan menerapkan pembelajaran MEAs berbantuan masalah open endedserta tanggapan siswa kelas X IPA 3 SMA Negeri 1 Baturiti terhadap model eliciting activities (MEAs) berbantuan masalah open ended.

\section{METODE}

Penelitian ini merupakan penelitian tindakan kelasyang bertujuan untuk meningkatkan dan memperbaiki proses pembelajaran di kelas X IPA 3 SMA Negeri 1 Baturiti yang berdampak pada peningkatan pemahaman konsep matematika siswa.

Subjek dalam penelitian ini adalah siswa kelas X IPA 3 SMA Negeri 1 Baturitiyang berjumlah 34 orang.Desain penelitian tindakan kelas yang dipergunakan dalam penelitian ini adalah model Kemmis dan McTaggart. Menurut Kemmis dan Mc. Taggart (dalam Heris \& Afrilianto, 2017: 44), pelaksanaan tindakan dalam Penelitian Tindakan Kelas (PTK) meliputi empat langkah: (1) perencanaan tindakan; (2) pelaksanaan tindakan; (3) observasi; dan (4) refleksi.

Data mengenai kemampuan pemahaman konsep siswa diperoleh melalui tes pemahaman konsep yang dilakukan pada setiap akhir siklus untuk mengukur kemampuan pemahaman konsep siswa.Sedangkan, data tanggapan siswa terhadap penerapan model eliciting activities berbantuan masalah open ended diperoleh melalui angkettanggapanyang terdiri dari 15 butir pernyataan yang diberikan pada akhir siklus III.

Data mengenai kemampuan pemahaman konsep siswa dianalisis berdasarkan ratarata nilai yang telah ditetapkan yaitu minimal 70sesuai dengan Ketuntasan Belajar Minimum (KBM)mata pelajaran matematika di kelas X IPA 3 SMA Negeri 1 Baturiti, sehingga kriteria ketuntasan pemahaman konsepmatematika siswa disajikan pada Tabel 1.

Tabel 1. Kriteria Ketuntasan Pemahaman Konsep Matematika

\begin{tabular}{ccc}
\hline No & Rentangan Skor & Kategori \\
\hline 1. & $70 \leq \bar{X} \leq 100$ & Tuntas \\
2. & $0 \leq \bar{X}<70$ & Belum Tuntas \\
\hline
\end{tabular}

Dengan diperolehnya rata-rata nilai pemahaman konsep untuk setiap siklus, maka dapat ditentukan kemampuan pemahaman konsep metematika siswa dari siklus I sampai siklus III. 
Sedangkan data tanggapan siswaterhadap penerapan model eliciting activities berbantuan masalah open ended dianalisis secara deskriptif,yaitu dengan menghitung ratarata skor tanggapan siswa dengan kriteria penggolongan yang disajikan pada Tabel 2.

Tabel 2. Kriteria Penggolongan Tanggapan Siswa

\begin{tabular}{cc}
\hline Rentangan Skor & Kriteria \\
\hline $\bar{R} \geq 63$ & Sangat Positif \\
$51 \leq \bar{R}<63$ & Positif \\
$39 \leq \bar{R}<51$ & Cukup Positif \\
$27 \leq \bar{R}<39$ & Negatif \\
$\bar{R}<27$ & Sangat Negatif \\
\hline
\end{tabular}

Dari analisis data tersebut, penelitian ini menetapkan kriteria keberhasilan yaitu: (1) rata-rata nilai pemahaman konsep matematika siswa meningkat dari siklus ke siklus dengan rata-rata nilai mencapai nilai $\mathrm{KBM} \geq 70$ serta secara klasikal $65 \%$ siswa mencapai kriteria tuntas, dan (2) tanggapan siswa terhadap penerapanmodel eliciting activities (MEAs) berbantuan masalah open ended dilihat dari rata-rata skor tanggapan siswa minimal dalam kategori positif.

\section{HASIL DAN PEMBAHASAN}

\section{A. HASIL}

Berdasarkan hasil penelitian yang telah dilaksanakan, berikut disajikan peningkatan rata-rata nilai pemahaman konsep matematikasiswa di kelas X IPA 3 SMA Negeri 1 Baturiti,serta persentase ketuntasan mulai dari refleksi awal sampai siklus III pada Gambar 1a dan $1 b$,

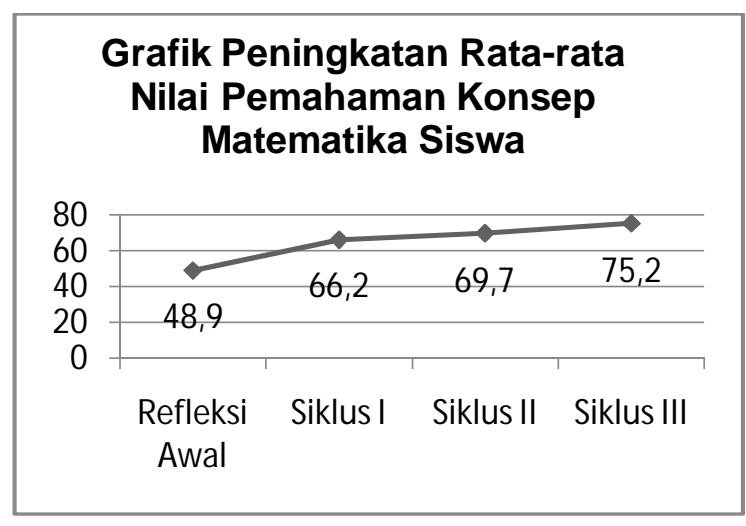

Gambar 1.a

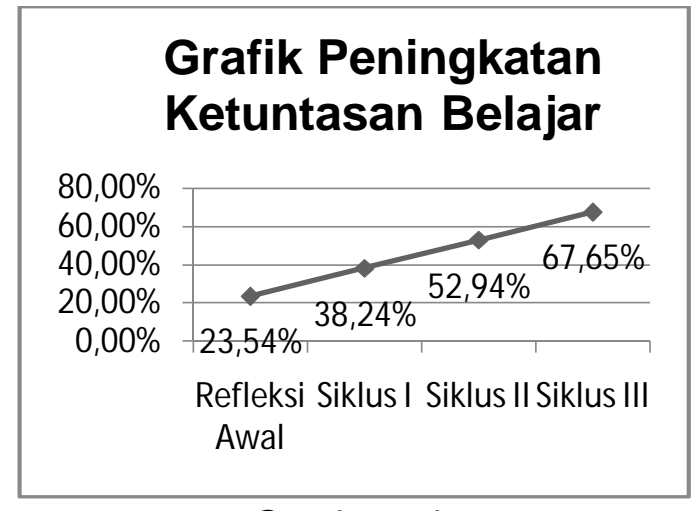

Gambar 1.b

Jurnal Pendidikan dan Pembelajaran Matematika Indonesia 137 
Berdasarkan Gambar 1a dan 1b. Dapat ditunjukkan bahwa nilai rata-rata pemahaman konsep matematika siswa telah mengalami peningkatan dari refleksi awal sampai ke siklus III, pada siklus III rata-rata nilai pemahaman konsep siswa adalah 75,20 sehingga telah berada dalam kategori tuntas denganketuntasan siswa secara klasikal adalah $67,65 \%$.

Pada akhir siklus III siswa diberikan angkettanggapan yang bertujuan untuk mengetahui tanggapan siswa terhadap penerapan model eliciting activities berbantuan masalah open ended.Adapun sebaran data tanggapan siswa dapat dilihat pada Gambar 2.

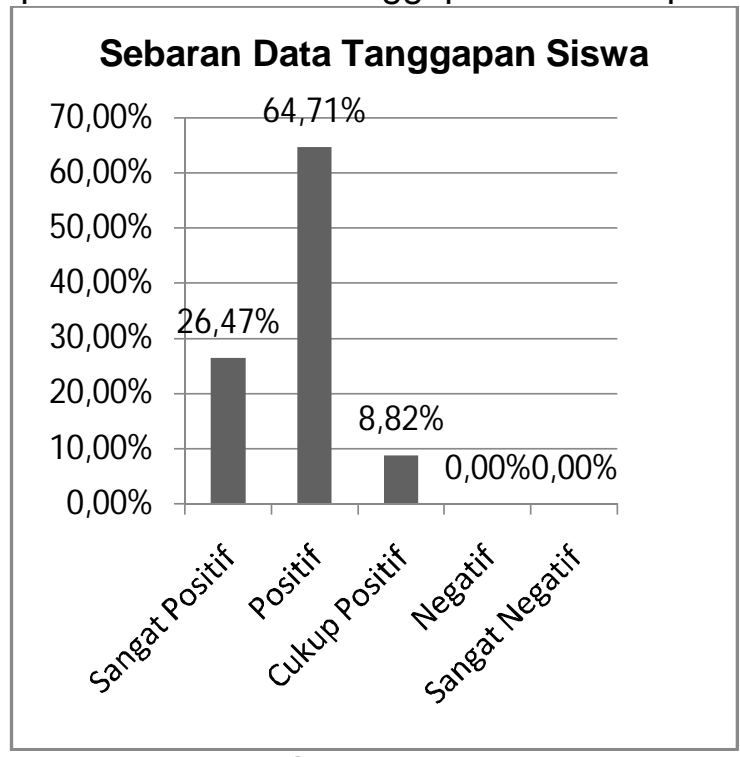

Gambar 2.

Berdasarkan Gambar 2, terlihat bahwa persentase siswa yang memberikan tanggapan sangat positif $26,47 \%$ (9 orang), tanggapan positif $64,71 \%$ (22 orang),dan tanggapan cukup positif $8,82 \%$ (3 orang) sedangkan rata-rata skor tanggapan siswa terhadap tehadap penerapan model eliciting activities berbantuan masalah open endedadalah 55,29 sehingga rata-rata skor tanggapan siswa berada dalam kategori positif.Berdasarkan hal tersebut, dapat dikatakan bahwa indikator keberhasilan pada penelitian ini telah terpenuhi

\section{B. PEMBAHASAN}

Berdasarkan hasil penelitian yang telah dilaksanakan selama tiga siklus, menunjukkan terjadinya peningkatan pemahaman konsep matematika siswa dari siklus ke siklus melalui penerapan pembelajaran MEAs berbantuan masalah open ended. Adapun hal-hal yang menyebabkan terjadinya peningkatan kemampuan pemahaman konsep yang dimiliki siswa adalah sebagai berikut.

Pertama, pembelajaran dengan menerapkan MEAsmemberikan kesempa-tan siswa untuk belajar matematika dengan lebih aktif. Pembelajaran MEAs menekankan pada aktivitas siswa dalam memunculkan suatu model matematika sebagai suatu solusi dari permasalahan yang diberikan. Aktivitas siswa dalam memunculkan model matematika tersebut berdasarkan langkah-langkah pembelajar-an pada MEAs. Selain itu, dengan diberikannya permasalahan yang bersifat kontekstual, membuat siswa tertarik dalam menyelesaikannya. Dengan kata lain proses pembelajaran akan lebih bermakna sehingga menjadikan siswa lebih memahami konsep matematika. Pada pembelajaran MEAs siswa juga dilatih untuk mengembangkan kreatifitas, ini menjadikan siswa akan lebih mandiri dalam menyelesaikan permasalahan yang ada serta mengkontruksi sendiri pengetahuannya. Hal ini sesuai dengan penelitian Martil (2015) yang menunjukkan model eliciting activities berpengaruh terhadap pemahaman konsep matematika siswa. Selain itu, pembelajaran 
MEAs mengajarkan siswa untuk bekerja dalam kelompok, pembentukan kelompok ini efektif untuk mengembangkan interaksi antar siswa terutama ketika menyelesaikan masalah. Hal tersebut sejalan dengan yang diungkapkan oleh Suherman, dkk (2003) bahwa dengan menerapkan pembelajaran kelompok dalam proses pembelajaran siswa dapat mendiskusikan masalah yang dihadapi, saling bertukar ide, dan memperdebatkan solusi yang akan digunakan.

Kedua, kegiatan pembelajaran menekankan siswa untuk mengkonstruksi sendiri pengetahuannya serta memberikan kesempatan kepada siswa untuk mengembangkan ide, gagasan atau cara yang digunakan untuk menyelesaikan permasalahan yang diberikan. Pada tahap ini materi disajikan dalam bentuk permasalahan pada LKS, permasalahan tersebut akan menggiring siswa pada materi pembelajaran yang akan disampaikan. Siswa diperkenalkan pada masalah open ended. Pemberian masalah open ended akan meningkatkan ketertarik-an siswa terhadap matematika, karena pemberian masalah open ended siswa dapat mengekplorasi sendiri pengetahuan dan ide-ide yang dimiliki oleh siswa. Hal ini didukung oleh pendapat Parwati (2012), bahwa dengan memberikan kebebasan pada siswa untuk menemukan jawaban sesuai dengan kemampuan siswa, mereka tidak akan merasa terbebani dalam belajar matematika. Berdasarkan uraian tersebut pemberian masalah open ended sebagai salah satu upaya untuk meningkatkan pemahaman konsep matematika siswa ditunjukkan oleh hasil penelitian yang dilaksanakan oleh Sidanta (2011) yang menyatakan bahwa terdapat pengaruh pembelajaran berbasis masalah open ended terhadap pemahaman konsep matematika siswa, hasil penelitian tersebut menunjukkan bahwa pembelajar-an dengan berbasis masalah open-ended lebih baik dibandingkan dengan pembelajaran konvensional.

Ketiga, peran guru dalam kegiatan pembelajaran. Guru senantiasa mem-bimbing dan menuntun siswa, terutama siswa yang memiliki kesulitan dalam memamahi permasalahan yang diberikan. Guru meminta siswa untuk mencermati dengan membaca berulang permasalahan yang ada, menuntun siswa untuk menemukan informasi atau pernyataan yang diketahui (current state) serta pernyataan yang akan dituju (goal state) dalam suatu masalah. Peran guru tersebut sesuai dengan yang disampaikan oleh Sudiarta (2008) bahwa guru berperan sebagai fasilitator dalam proses pembelajaran memiliki pengertian bahwa guru selalu membimbing dan mengarahkan siswa dalam proses penyelesaian masalah open ended.

Keempat, guru juga memberikan motivasi kepada siswa yang belum terlibat aktif dalam kegiatan pembelajaran. Seperti yang diketahui pada kegiatan diskusi siklus I dan II masih didomonasi oleh siswa yang sama padahal pemberian masalah open ended seharusnya mampu mendorong siswa untuk memiliki jawaban dan cara yang berbeda dengan siswa yang lainnya. Maka dari itu, pemberian motivasi kepada siswa lainnya untuk dapat berpartisipasi dalam kegiatan pembelajar-an sangatlah penting.

Selain itu, peningkatan yang telah dicapai tidak terlepas dari penerapan model pembelajaran MEAs berbantuan masalah open ended dengan tahap-tahap yang terdapat dalam MEAs yang diberikan yaitu adanya kegiatan diskusi dan melatih siswa untuk belajar lebih bermakna. Hal ini disebabkan karena siswa diberikan permasalahan open ended sehingga siswa lebih dapat mengekplorasi ide, gagasan, dan pengetahuan yang dimilikinya. Selain itu penerapan model pembelajaran MEAs berbantuan masalah open ended ini mendorong siswa berperan aktif dalam proses pembelajaran.

Beberapa langkah-langkah yang dimiliki oleh model pembelajaran MEAs berbantuan masalah open ended antara lain yaitu (1)mencermati masalah, pada tahap ini siswa diberikan masalah yang open ended yang bertujuan agar siswa tidak hanya terpaku pada hasil akhir saja, melainkan siswa juga mampu menemukan sendiri hal-hal yang kurang pada masalah yang disajikan. Hal ini menjadikan kemampuan berpikir siswa lebih meningkat, karena untuk menyelesaikan masalah open ended diperlukan kreatifitas siswa agar soal yang diberikan memperoleh hasil yang benar. Tentu saja jawaban yang diberikan harus sesuai dengan masalahnya; (2) memberikan jawaban sementara atas permasalahan, pada

Jurnal Pendidikan dan Pembelajaran Matematika Indonesia| 139 
tahap ini siswa harus mencari fakta-fakta dari informasi yang terdapat pada masalah dengan memperhatikan hal-hal apa saja yang diketahui pada permasalahan. Ini akan memudahkan siswa untuk menyederhanakan ilustrasi pada permasalahan; (3) mendiskusikan solusi permasalahan, pada tahap ini siswa bersama kelompok melakukan diskusi yang mana tiap anggota kelompok mempunyai kewajiban dalam menyampai-kan ide ataupun gagasan yang dimiliki untuk solusi pada permasalahan. Pada tahap ini siswa akan belajar untuk menghargai dan mendengarkan pendapat orang lain dan mencari solusi bersama-sama dalam penyelesaian permasalahan; (4) menyempurnakan solusi permasalah-an, pada tahap ini siswa menyusun model matematika dari jawaban sementara yang telah dibuat. Menyusun model matematika akan membiasakan siswa agar membuat permasalahan menjadi lebih sederhana dan memudahkan siswa dalam menyelesaikan permasalahan; (5) membuat penyelesaian sistematis, pada tahap ini siswa mulai membuat penyelesaian dari permasalahan yang diberikan dari hasil diskusi yang telah dilakukan siswa bersama kelompok; (6) menguji dan merevisi solusi permasalah-an, pada tahap ini siswa menguji penyelesaian yang telah dibuat. Tahap ini siswa mengemukaan kembali pendapat-nya jika ada hal yang harus direvisi maupun dirubah; (7) mempresentasikan solusi permasalahan, pada tahap terakhir ini siswa yang menjadi perwakilan kelompok mempresentasikan hasil diskusinya bersama kelompok.

Dari kegiatan tersebut, guru dapat mengetahui seberapa jauh pemahaman siswa terhadap konsep yang dipelajari dengan pengalaman belajar yang diperoleh siswa dalam menemukan konsep-konsep baru dan lebih memahami konsep yang mereka pelajari. Hal ini sejalan dengan penelitian yang dilakukan dengan Wawan (2017) yang menunjukkan pembelajaran model eliciting activities dengan pendekatan open ended lebih baik daripada yang mendapat pembelajaran konvensional.

Selain itu, juga akan membuat siswa menyadari bahwa belajar matematika bukan hanya terpaku pada hasil akhir saja, tetapi proses untuk mendapatkan jawaban akhir tersebut juga penting. Hal ini membuat siswa menyadari bahwa pentingnya untuk mereka memahami konsep dari suatu materi yang akan membuat mereka lebih mudah dalam menerapkan konsep tersebut. Dengan demikian, pembelajaran akan menjadi lebih bermakna. Sesuai dengan pendapat Basir (2016), pemahaman terhadap konsep-konsep matematika merupakan dasar untuk belajar matematika secara bermakna.

Berdasarkan hasil pengamatan selama melaksanakan penelitian, siswa tampak antusias dan bekerja sama dengan baik dalam kelompok untuk mengerjakan masalah open ended. Hal ini didukung pula oleh tanggapan siswa terhadap pembelajaran yang tergolong positif. Akan tetapi, walaupun hampir seluruh siswa memberikan respon positif terhadap penerapan pembelajaran MEAs berbantuan masalah open ended, masih terdapat siswa yang mengalami kesulitan ketika diterapkannya model pembelajaran MEAs berbantuan masalah open ended. Beberapa siswa mengatakan bahwa memiliki kesulitan dalam mengikuti petunjuk LKS dan memahami permasalah-an yang diberikan serta lebih nyaman atau menyenangi kegiatan pembelajaran ketika guru yang menjelaskan dibandingkan dengan diskusi kelompok yang mengharuskan siswa untuk mengkonstruksi dan mengeksplorasi pengetahuannya sendiri. Hal ini disebabkan karena siswa telah terbiasa dengan model pembelajaran yang diterapkan oleh gurunya sehingga beberapa siswa masih menyesuaikan diri dengan diterapkannya pembelajaran MEAs berbantuan masalah open ended. Namun secara umum, siswa kelas X IPA 3 telah merespon positif penerapan pembelajaran MEAs dengan masalah open ended, ini berarti model pembelajaran MEAs berbantuan soal open ended menjadi salah satu alternatif solusi untuk pembelajaran di kelas. 


\section{KESIMPULAN DAN SARAN}

\section{A. KESIMPULAN}

Berdasarkan hasil penelitian dan pembahasan mengenai penerapan model eliciting activities (MEAs) berbantuan masalah open ended di kelas X IPA 3 SMA Negeri 1 Baturiti, dapat disimpulkan hal-hal sebagai berikut: (1) Penerapan model eliciting activities (MEAs) berbantuan masalah open ended dapat meningkatkan pemahaman konsep matematika siswa yang ditandai dengan peningkatan dari siklus I ke siklus II dari rata-rata 66,2 dengan ketuntasan klasikal 38,24\% pada siklus I menjadi 69,7 dengan ketuntasan klasikal 52,94\% pada siklus II. Kemudian dari siklus II ke siklus III mengalami peningkatan menjadi 75,2 dengan ketuntasan klasikal $67,65 \%$, serta telah memenuhi indikator keberhasilan yakni mencapai 70 dan ketuntasan belajar secara klasikal $\geq 65 \%$. (2) Tanggapan siswa terhadap model eliciting activities (MEAs) berbantuan masalah open ended berada dalam kategori positif dengan rata-rata skor tanggapan siswa adalah 55,29.

\section{B. SARAN}

Berdasarkan hasil penelitia ini, disampaikan beberapa saran sebagai berikut: (1) Diharapkan Model Eliciting Activities (MEAs) dapat dijadikan salah satu alternatif dalam melaksanakan pembelajaran matemtaika, sehingga pembelajaran yang dilaksanakan lebih variatif seperti yang telah dilaksanakan sebelumnya dan dapat meningkatkan pemahaman konsep matematika siswa. (2) Kepada pembaca yang berminat untuk mengadakan penelitian lebih lanjut sebagai penyempurnaan mengenai Model Eliciting Activities (MEAs) dengan memperhatikan kendala-kendala yang peneliti alami sebagai bahan pertimbangan

\section{DAFTAR PUSTAKA}

Basir, Fahrul. 2016. "Keefektifan Strategi Konflik Kognitif Terhadap Pemahaman Konsep Matematika Siswa”. Cokroaminoto Palopo University Journal Vol. 2 No. 1.

Heris dan Afrilianto.2017.Penelitian Tindakan Kelas Bagi Guru.Cimahi: Refika Aditama.

Lesh, Doer. 2003. Model Eliciting Activities. Tersedia: www.ijsr.net/ART20174533 (4 Maret 2018)

Martil, Izzati. 2015. Pengaruh Penerapan Model Eliciting Activities (MEAs) pada Pembelajaran Matematika Terhadap Kemampuan Pemahaman Konsep Siswa Kelas IX MTsN IV Angkat Candung. Sumatera: STAIN Busungsangkar. Tersedia: ecampus.iainbatusangkar.ac.id

NCTM. 2000. Mathematics Assessment: A Practical Handbook for Grades 6-8. USA: LCC.

Parwati, NN. 2012. "Pengembangan Perangkat Pembelajaran Matematika Berorientasi Open Ended Problem Solving". Jurnal IImu Pendidikan Vol. 18 No. 1

Sidanta, GK. 2011. Pembelajaran Matematika Berbasis Masalah Open Ended Untuk Meningkatkan Kemampuan Pemahaman Konsep Matematis. Universitas Negeri Lampung

Sudiarta, I. G. P. 2008. Membangun Kompetensi Berpikir Kritis Melalui Pendekatan Open Ended. Singaraja: Unit Penerbitan Undiksha.

Suherman, Erman.2003.Strategi Pembelajaran Matematika Konteporer.Bandung: Jurusan Pendidikan Matematika FMIPA UPI.

Wawan, dkk. 2017. Pengaruh Model Pembelajaran Eliciting Activities dengan Pendekatan Open EndedProblem Terhadap Kemampuan Pemecahan Masalah Matematika Siswa Kelas VIII SMP $N{ }_{1}$ Tabanan. Singaraja: Undiksha. Tersedia: ejournal.undiksha.ac.id/index.php/JJPM 
Jurnal Pendidikan dan Pembelajaran Matematika Indonesia

Vol. 8 No. 2, Tahun 2019

e-ISSN : 2615-7454

Jurnal Pendidikan dan Pembelajaran Matematika Indonesia | 142 